\title{
STUDI KOMPARASI METODE PEMBELAJARAN KOOPERATIF STUDENT TEAMS ACHIEVEMENT DIVISION (STAD) DAN NUMBERED HEAD TOGETHER (NHT) BERBANTUAN MEDIA HANDOUT TERHADAP PRESTASI BELAJAR SISWA MATERI SISTEM PERIODIK UNSUR KELAS X SMA NEGERI 2 SUKOHARJO TAHUN PELAJARAN 2015/2016
}

\author{
Humaira, Sulistyo Saputro*, dan Widiastuti Agustina Eko Setyowati \\ Program Studi Pendidikan Kimia, FKIP, Universitas Sebelas Maret, Surakarta, Indonesia \\ *Keperluan korespondensi, telp/fax:081329196891, email: sulistyo68@yahoo.com
}

\begin{abstract}
ABSTRAK
Penelitian ini bertujuan untuk mengetahui: efektifitas penggunaan metode pembelajaran kooperatif Student Teams Achievement Division (STAD) dan Numbered Head Together (NHT) berbantuan media handout terhadap prestasi belajar siswa materi Sistem Periodik Unsur kelas $\mathrm{X}$ SMA 2 Sukoharjo tahun pelajaran 2015/2016. Penelitian ini menggunakan metode eksperimen dengan desain Randomized Postest Comparison Design. Populasi yang digunakan dalam penelitian ini adalah siswa kelas X SMA Negeri 2Sukoharjo tahun pelajaran 20152016 yang terdiri dari 8 kelas. Sampel penelitian adalah siswa kelas X IPS 1 dan kelas X IPS 2 SMA Negeri 2 Sukoharjo tahun pelajaran $2015 / 2016$. Pengambilan sampel pada penelitian ini menggunakan cluster random sampling. Teknik pengumpulan data menggunakan: (1) instrument tes untuk mengukur kemampuan prestasi belajar aspek pengetahuan; (2) angket untuk mengukur prestasi belajar aspek sikap; (3) observasi untuk mengukur prestasi belajar aspek sikap dan keterampilan. Hasil penelitian menunjukkan bahwa penggunaan metode pembelajaran Numbered Head Together (NHT) disertai media handout lebih efektif dibandingkan dengan metode pembelajaran Student Teams Achievement Division (STAD) disertai media handout pada pokok bahasan sistem periodik unsur kelas X SMA Negeri 2 Sukoharjo tahun pelajaran 2015/2016 pada prestasi belajar siswa aspek pengetahuan, tetapi menghasilkan prestasi belajar yang sama pada aspek sikap dan keterampilan.
\end{abstract}

Kata Kunci : Student Team Achievement Division (STAD), Numbered Head Together (NHT), Handout, Prestasi Belajar, Sistem Periodik Unsur.

\section{PENDAHULUAN}

Pendidikan merupakan salah satu aspek kehidupan yang senantiasa menjadi prioritas dalam mengembangkan harkat dan martabat individu, masyarakat dan bangsa. Undangundang Nomor 20 Tahun 2003 tentang Sistem Pendidikan Nasional menyebutkan bahwa pendidikan nasional berfungsi mengembangkan kemampuan dan membentuk watak serta peradaban bangsa yang bermartabat dalam rangka mencerdas-kan kehidupan bangsa [1]. Melalui pendidikan akan dihasilkan manusia-manusia terdidik sebagai sumber daya manusia ber-kualitas yang akan berperan dalam pembangunan. Perkembangan tek-nologi yang cepat dan sistem informasi yang semakin canggih mempunyai dampak yang luas dalam bidang pendidikan. Dampakdampak itu mendorong adanya berbagai usaha pembaharuan dalam bidang pendidikan. Oleh karena itu, pemerintah secara bertahap dan terus menerus berupaya meningkatkan kualitas dan kuantitas pendidikan.

Salah satu usaha pemerintah dalam meningkatkan mutu pendidikan adalah dengan mengadakan perombakan dan pembaharuan kurikulum yang 
berkesinambungan. Kurikulum yang saat ini sedang dikembangkan oleh pemerintah adalah kurikulum 2013 sebagai pengembangan dari Kurikulum Tingkat Satuan Pendidikan (KTSP). Prinsip yang digunakan dalam kurikulum 2013 adalah pembelajaran yang berpusat pada siswa, mengembangkan kreativitas peserta didik, menciptakan kondisi yang menyenangkan dan menantang, bermuatan nilai, etika, estetika, logika, dan kinestetika, serta menyediakan pengalaman belajar yang beragam melalui penerapan berbagai strategi dan metode pembelajaran yang menyenangkan, kontekstual, efektif, efisien, dan bermakna.

Dalam proses belajar mengajar pemilihan dan penggunaan metode pembelajaran yang tepat dalam menyajikan suatu materi dapat membantu siswa dalam mempelajari serta memahami segala sesuatu yang disajikan guru, sehingga melalui tes hasil belajar dapat diketahui peningkatan prestasi belajar siswa. Melalui pembelajaran yang tepat, siswa diharapkan mampu memahami dan menguasai materi ajar sehingga dapat berguna dalam kehidupan nyata. Salah satu indikator keberhasilan proses belajar mengajar dapat dilihat dari prestasi belajar yang dicapai siswa. Prestasi belajar adalah cermin dari pengetahuan, keterampilan dan sikap.

Pembelajaran kooperatif menitik beratkan pada proses belajar dalam kelompok dan bukan mengerjakan sesuatu bersama kelompok [2]. Proses belajar dalam kelompok akan membantu siswa menemukan dan membangun pemahaman mereka tentang materi pelajaran yang tidak dapat ditemui pada metode konvensional. Pada metode pembelajaran kooperatif menuntut semua siswa aktif dalam belajar dan harus selalu memperhatikan temannya untuk dapat berkompetisi dengan kelompok lain.

Metode pembelajaran kooperatif yang dapat digunakan dalam menyampaikan materi Sistem Periodik Unsur adalah metode STAD dan NHT. Hal ini dikarenakan materi Sistem Periodik Unsur memiliki beberapa alasan yaitu materi Sistem Periodik Unsur merupakan salah satu pokok bahasan dalam pelajaran kimia yang relatif baru bagi siswa kelas X SMA dan merupakan materi dasar dalam kimia. Dalam materi tersebut terdapat konsep-konsep yang memerlukan pemahaman dan hafalan yang cukup dari siswa seperti pemahaman tentang konfigurasi elektron, golongan dan periode dalam menentukan letak unsur serta keteraturan jarijari, energi ionisasi, afinitas elektron dan keelektronegatifan dalam Sistem peridik Unsur [3]. Untuk itu perlu cara mudah untuk menyampaikan kepada siswa dengan metode pembelajaran yang bervariasi agar siswa lebih aktif belajar dan tidak cepat bosan. Dengan metode pem-belajaran kooperatif STAD dan NHT diharapkan siswa lebih mudah mengusai konsep-konsep yang ada dalam materi Sistem Periodik Unsur.

Sistem Periodik Unsur me-rupakan salah satu materi dalam pembelajaran kimia yang dianggap sulit. Hal ini dapat dilihat dari data ketuntasan siswa materi Sistem Periodik Unsur SMA Negeri 2 Sukoharjo yaitu pada tahun pelajaran 2012/2013, 2013/2014, dan 2014/2015 secara berturut-turut yaitu $54,90 \%$, $52,78 \%$, dan $55,22 \%$.

Pada metode STAD siswa belajar materi dan mengerjakan soal dalam kelompoknya. Setiap kesulitan dalam memahami materi dan mengerjakan soal dicari penyelesaiannya secara bersamasama. Penyampaian pengetahuan dari teman-teman satu kelompoknya dengan bahasa mereka sendiri memudahkan mereka mengerti dan memahami materi. Dalam metode ini siswa memiliki tanggung jawab untuk mengerjakan tugas dan memahami materi untuk keberhasilan dirinya dan juga bagi keberhasilan anggota kelompoknya sesuai dengan tujuan pembelajaran yang telah ditetapkan. Adanya penghargaan kelompok dapat memotivasi setiap individu untuk memberi sumbangan bagi kelompoknya dengan meningkat-kan prestasi dirinya terlebih dahulu. Dengan demikian diharapkan metode STAD ini dapat menumbuhkan keaktifan, interaksi siswa, dan memotivasi siswa dalam kelompok untuk mencapai keberhasilan dalam belajarnya.

Sedangkan pada metode pembelajaran kooperatif NHT menekankan kerja- 
sama siswa pada saat mengerjakan soal-soal latihan dan penyampaian hasil diskusi oleh siswa dengan nomor yang ditunjuk guru. Pada metode pembelajaran NHT tidak terdapat penghargaan kelompok sehingga siswa kurang termotivasi. Pada metode pembelajaran NHT ini memberikan kesempatan kepada siswa untuk saling membagikan ide, mempertimbangkan jawaban yang paling tepat dan meningkatkan semangat kerjasama dalam kelompok. Dalam metode pembelajaran NHT siswa dalam kelompok mendapatkan tugas masingmasing dalam memecahkan soal-soal yang berbeda-beda antar anggotanya. Siswa diajak mengerjakan sendiri soalnya masing-masing dan saling membantu dalam menyelesaikan soal tersebut jika menemui kesulitan, sehingga diharapkan dengan latihan soal-soal bersama, siswa dapat memahami materi yang dibahas. Dengan latihan soal-soal dan mencari penyelesaiannya maka siswa akan menemukan pemahamannya sendiri dengan bantuan teman dalam kelompoknya. Dengan metode pembelajaran NHT ini, siswa diharapkan dapat terlibat aktif pada proses pembelajaran sehingga memberikan dampak positif terhadap kualitas interaksi dan komunikasi serta dapat memotivasi siswa untuk meningkatkan prestasi belajarnya.

Media handout digunakan pada setiap pertemuan dalam metode pembelajaran kooperatif STAD dan NHT. Penggunaan handout akan membantu siswa dalam menemukan konsep dari permasalahan yang ada. Dengan handout siswa dapat mencari penyelesaian dari permasalahan yang ada serta dapat digunakan sebagai pegangan siswa untuk belajar dirumah. Penggunaan handout pada metode pembelajaran kooperatif STAD dan NHT ini diharapkan dapat diterapkan pada materi Sistem periodik Unsur kelas X SMA Negeri 2 Sukoharjo, sehingga dari kedua metode tersebut dapat mendorong siswa untuk bekerjasama dan meningkatkan prestasi belajar siswa.

Penelitian ini didukung oleh penelitian sebelumnya, yang menyimpulkan bahwa pembejaran kimia dengan meng- gunakan model pembelajaran kooperatif tipe NHT (Numbe-red Head Together) lebih efektif daripada pembelajaran kimia dengan menggunakan model pembelajaran kooperatif tipe STAD (Student Teams Achievement Division) pada konsep laju reaksi [4]. Penelitian lain tentang penggunaan model pembelajaran Numbered Head Together (NHT) disertai bahan ajar modul lebih baik daripada model pembelajaran Student Teams Achievement Division (STAD) disertai bahan ajar modul terhadap prestasi belajar siswa pada materi pokok termokimia, baik dari prestasi belajar kognitif maupun afektif [5]. Peneliti lain menyimpulkan bahwa penerapan pembelajaran kooperatif STAD (Student Team Achievement Division) berbantuan macromedia flash dilengkapi handout dapat meningkatkan hasil belajar kimia materi pokok asam, basa, dan garam [6].

Dari alasan yang telah dikemukakan maka peneliti memakai metode pembelajaran kooperatif STAD dan NHT serta media handout. Dengan pemilihan metode pembelajaran koo-peratif STAD dan NHT serta media handout ini diharapkan siswa dapat lebih mudah menguasai konsep-konsep yang ada pada materi Sistem Periodik Unsur sehingga prestasi belajar siswa dapat lebih meningkat.

\section{METODE PENELITIAN}

Penelitian ini menggunakan metode eksperimen dengan desain Randomized Postest Comparison Design. Untuk lebih jelasnya, rancang-an penelitian dapat dilihat pada Tabel 1.

Tabel 1. Desain Penelitian Randomized Postest Comparison Design

\begin{tabular}{ccc}
\hline Kelompok & Perlakuan & Postes \\
\hline Eksperimen I & $\mathrm{X}_{1}$ & $\mathrm{~T}$ \\
Eksperimen II & $\mathrm{X}_{2}$ & $\mathrm{~T}$ \\
\hline
\end{tabular}

Keterangan:

$\mathrm{T} \quad$ : nilai postes/ujian

$\mathrm{X}_{1} \quad$ : penggunaan metode pembelajaran kooperatif STAD dengan media handout 
$\mathrm{X}_{2}$ : penggunaan metode pembelajaran kooperatif NHT dengan media handout

Penelitian ini dilakukan di SMA Negeri 2 Sukoharjo. Populasi yang dignakan dalam penelitian adalah siswa kelas X SMA Negeri 2 Sukoharjo tahun pelajaran 20152016. Sampel yang terpilih adalah siswa kelas $X$ IPS 1 sebagai kelas eksperimen I yang diberi perlakuan metode pembelajaran kooperatif Student Teams Achievement Division (STAD) dengan media handout dan X IPS 2 sebagai kelas eksperimen II yang diberi perlakuan metode pembelajaran kooperatif Numbered Head Together (NHT) dengan media hand-out. Pengambilan sampel pada penelitian ini menggunakan cluster random sampling. Teknik pengumpulan data menggunakan: (1) instrumen tes untuk mengukur kemampuan prestasi belajar aspek pengetahuan; (2) angket untuk mengukur kemampuan prestasi belajar aspek sikap; (3) observasi untuk mengukur kemampuan prestasi belajar aspek sikap dan keterampilan.

Teknik analisis data terdiri dari uji prasyarat analisis dan uji hipotesis. Uji prasyarat analisis meliputi uji nor-malitas, uji homogenitas dan uji ke-samaan ratarata. Uji hipotesis dengan menggunakan bantuan software IBM SPSS version 21. Analisis data prestasi belajar aspek pengetahuan mengguna-kan uji statistik parametrik General Linear Model Univariate, sedangkan analisis data prestasi belajar aspek si-kap dan aspek keterampilan meng-gunakan uji statistik non parametrik Mann Whitney.

Instrumen yang digunakan dalam penelitian ini dibedakan menjadi dua yaitu instrumen pembelajaran dan instrumen penilaian. Instrumen pembelajaran terdiri dari silabus, RPP, dan media pembelajaran. Sedangkan instrumen penilaian terdiri dari instrumen penilaian aspek sikap, pengetahuan dan keterampilan. Teknik analisis instrumen pembelajaran menggunakan uji validitas isi dengan formula Gregory.

Teknik analisis angket aspek sikap dan penilaian observasi menggunakan uji validitas isi, diperoleh nilai CV untuk angket penilaian diri dan lembar observasi berturut-turut sebesar 0,825 dan 0,975. Uji reliabilitas menggunakan rumus Alpha. Hasil uji coba reliabilitas angket penilaian diri 0,786.

Teknik analisis instrumen aspek pengetahuan menggunakan uji validitas isi diperoleh nilai CV sebesar 0,8 dan uji reliabilitas menggunakan rumus KR-20 diperoleh nilai sebesar 0,733 . Selain itu, instrumen penilaian pengetahuan juga diuji tingkat kesukaran soal dan daya pembedanya menggunakan Microsoft exel. Setelah dilakukan analisis terhadap hasil uji coba instrumen penilaian pengetahuan diperoleh ke-simpulan bahwa dari 25 soal yang diuji cobakan, 1 soal tergolong sukar, 17 soal tergolong sedang, dan 7 soal ter-golong mudah. Dari 25 soal tersebut, juga disimpulkan bahwa daya pembeda 7 soal tergolong baik, 13 soal tergolong cukup, dan 5 soal tergolong jelek.

Teknik analisis penilaian observasi aspek keterampilan menggunakan uji validitas isi, diperoleh nilai CV sebesar 1,00 .

\section{HASIL DAN PEMBAHASAN}

Data yang diperoleh adalah data prestasi belajar siswa meliputi aspek sikap,pengetahuan dan keterampilan. Data tersebut dirangkum dalam Tabel 2.

Tabel 2. Rangkuman Deskripsi Data Penelitian

\begin{tabular}{|c|c|c|}
\hline \multirow[b]{2}{*}{$\begin{array}{c}\text { Jenis } \\
\text { Penilaian }\end{array}$} & \multicolumn{2}{|c|}{ Nilai Rata-rata } \\
\hline & $\begin{array}{c}\text { Kelas } \\
\text { Eksperimen I }\end{array}$ & $\begin{array}{c}\text { Kelas } \\
\text { Eksperimen II }\end{array}$ \\
\hline Pengetahuan & 2,68 & 2,86 \\
\hline Sikap & 3,167 & 3,139 \\
\hline Keterampilan & 3,809 & 3.789 \\
\hline
\end{tabular}

Pada tahap awal, dilakukan analisis terhadap kondisi awal siswa. Analisis ini didasarkan atas nilai Ulangan Harian kimia semester gasal tahun pelajaran 2015/2016. Kedua kelas diuji normalitas, homogenitas dan kesamaan rata-rata. Dari uji normalitas menggunakan Kolmogorov-Smirnov diperoleh hasil bahwa kedua kelas berdistribusi normal. 
Dari uji homogenitas menggunakan Levene statistic diperoleh hasil bahwa kedua kelas homo-gen. Sedangkan dari uji kesamaan rata-rata diperolah hasil bahwa kedua kelas tidak memiliki perbedaan rata-rata nilai Ulangan Harian kimia semester gasal tahun pelajaran 2015/2016 (kemampuan awal setara).

Sebelum dilakukan uji hipotesis dilakukan uji persyaratan analisis meliputi uji normalitas dan uji homogenitas. Setelah dilakukan uji persyaratan analisis, selanjutnya pengujian hipotesis menggunakan uji statistik parametrik independent sample t-test dan nonparametrik menggunakan uji Mann Whitney.

Pada uji hipotesis yang terangkum dalam tabel 3, hasil pengujian independent sample t-test aspek pengetahuan untuk mengetahui 2 metode pembelajaran yang diterapkan dengan media yang sama menunjukkan bahwa nilai Sig. $(0,034)<\alpha(0,05)$ sehingga $H_{0}$ ditolak. Dapat disimpulkan bahwa ratarata prestasi belajar siswa kelas eksperimen I lebih kecil atau sama dengan siswa kelas eksperimen II $(\mu 1 \leq$ $\mu 2)$ terhadap prestasi belajar aspek pengetahuan siswa pada materi sistem periodik-unsur.

Tabel 3. Rangkuman Hasil Uji Hipotesis Prestasi Belajar Aspek Pengetahuan Siswa

\begin{tabular}{lcccc}
\hline \multicolumn{1}{c}{ Sumber } & Jenis Uji & $\begin{array}{c}\text { Signifikansi (Sig.)/ } \\
\text { (Asymp. Sig.) }\end{array}$ & $\alpha$ & Keputusan \\
\hline Metode & $\begin{array}{c}\text { independent } \\
\text { sembelajaran }\end{array}$ & 0,034 & 0,050 & $\mathrm{H}_{0}$ ditolak \\
\hline
\end{tabular}

Tabel 4. Rangkuman Hasil Uji Hipotesis Prestasi Belajar Aspek Sikap Siswa

\begin{tabular}{lcccc}
\hline \multicolumn{1}{c}{ Sumber } & Jenis Uji & Signifikansi (Sig.) & $\alpha$ & Keputusan \\
\hline $\begin{array}{l}\text { Metode } \\
\text { Pembelajaran }\end{array}$ & Mann Whitney & 0,975 & 0,050 & $\mathrm{H}_{0}$ diterima \\
\hline
\end{tabular}

Tabel 5. Rangkuman Hasil Uji Hipotesis Prestasi Belajar Aspek Keterampilan Siswa

\begin{tabular}{lcccc}
\hline \multicolumn{1}{c}{ Sumber } & Jenis Uji & $\begin{array}{c}\text { Signifikansi (Sig.) / } \\
\text { (Asymp. Sig.) }\end{array}$ & $\alpha$ & Keputusan \\
\hline $\begin{array}{l}\text { Metode } \\
\text { Pembelajaran }\end{array}$ & Mann Whitney & 0,870 & 0,050 & $\mathrm{H}_{0}$ diterima
\end{tabular}

Berdasarkan hasil pengujian hipotesis terhadap prestasi belajar pengetahuan, sikap, dan keterampilan yang bertujuan untuk mengetahui efektifitas penggunaan metode pembelajaran kooperatif Student Teams Achievement Division (STAD) dan Numbered Head Together (NHT) berbantuan media handout terhadap prestasi belajar siswa materi Sistem Periodik Unsur. Metode pembelajaran yang diterapkan oleh guru hendaknya metode pembelajaran yang bisa membuat siswa menjadi aktif dan kreatif serta berlangsung efektif dan menyenangkan sehingga prestasi belajar siswa menjadi lebih baik. Selain itu, metode pembelajaran yang diterapkan harus disesuaikan dengan karakteristik materi dan tujuan pembelajaran.

Materi sistem periodik unsur merupakan salah satu materi pokok yang dipelajari dalam kimia. Cakupan materi sistem periodik unsur meliputi perkembangan sisten periodik unsur, penentuan letak suatu unsur dalam tabel periodik melalui konfigurasi elektron dan sifatsifat periodik unsur. Dalam mempelajari sistem periodik unsur, siswa bukan hanya dituntut untuk memiliki daya ingat yang tinggi, akan tetapi juga harus memiliki pemahaman yang baik agar dapat menganalisis suatu permasalahan. Apabila guru menerapkan metode ceramah dalam pembelajaran maka siswa cepat merasa bosan dan pembelajaran menjadi kurang menye- 
nangkan, sehingga siswa tidak tertarik mengikuti pelajaran. Akibatnya prestasi belajar siswa menjadi rendah. Berdasarkan hal tersebut, peneliti menerapkan metode pembelajaran STAD dan NHT yang disertai media handout. Kedua metode ini dapat mempermudah proses belajar siswa dan dapat membuat siswa aktif dalam mempelajari sistem periodik unsur.

Dilihat dari uji statistik prestasi belajar aspek pengetahuan dari kedua kelas, prestasi belajar aspek pengetahuan dalam kelas NHT memiliki hasil yang lebih tinggi dibandingkan dalam kelas STAD. Hal ini dikarenakan metode NHT lebih ditekankan pada diskusi secara bersama-sama sehingga komunikasi yang disampaikan dan kerjasama yang terjalin pada setiap kelompok mempengaruhi hasil prestasi belajar siswa dalam pembelajaran materi Sistem Periodik Unsur.

Metode STAD hampir sama dengan metode yang digunakan oleh guru pada saat mengajar yaitu dengan memberikan ceramah meskipun hanya diberikan dengan waktu yang singkat, ini adalah salah satu kekurangan dari metode STAD. Kekurangan metode STAD yang lain adalah kurangnya komunikasi dan kerjasama pada saat terbentuk tim sehingga membuat prestasi belajar siswa kurang maksimal dimana siswa yang merasa mampu tidak atau kurang ingin memberikan penjelasan kepada temannya. Hasil prestasi belajar siswa aspek pengetahuan yang diperoleh dalam penelitian ini dapat disimpulkan bahwa metode NHT berbantuan media handout memiliki hasil prestasi belajar yang lebih baik dibandingkan dengan metode STAD berbantuan media handout.

Berdasarkan data pada tabel 2 dapat disimpulkan bahwa penerapan kedua metode dengan media yang sama menghasilkan prestasi belajar yang sama pada aspek sikap. Ini berarti bahwa model pembelajaran bukan sebagai faktor penting pendorong sikap siswa. Perubahan perilaku sikap tidak berlangsung serta merta akan tetapi melalui proses yang membutuhkan waktu lebih lama daripada aspek kognitif dan diperlukan dukungan dari lingkungan. Selain itu, prestasi belajar sikap ini ada yang tampak pada saat proses belajar-mengajar berlangsung dan ada pula yang baru tampak kemudian (setelah pengajaran diberikan) dalam praktik kehidupannya di lingkungan keluarga, sekolah, dan masyarakat [7].

Dari data pada tabel 2 dapat disimpulkan bahwa penerapan kedua metode dengan media yang sama menghasilkan prestasi belajar yang sama pada aspek keterampilan. Prestasi belajar aspek keterampilan siswa dinilai dari hasil presentasi sswa. Aspek keterampilan didukung oleh ketrampilan (skill) dan kemampuan dalam menyampaikan pendapat dan informasi.

\section{KESIMPULAN}

Berdasarkan hasil penelitian yang telah dilakukan dapat disimpulkan bahwa penggunaan metode pembelajaran Numbered Head Together (NHT) disertai media handout lebih efektif dibandingkan dengan metode pembelajaran Student Teams Achievement Division (STAD) disertai media handout pada pokok bahasan sistem periodik unsur kelas $X$ SMA Negeri 2 Sukoharjo tahun pelajaran 2015/2016 pada prestasi belajar siswa aspek pengetahuan, tetapi menghasilkan prestasi belajar yang sama pada aspek sikap dan keterampilan.

\section{UCAPAN TERIMA KASIH}

Penulis mengucapkan terima-kasih kepada Ibu Muthoyyinah, S.Pd., selaku guru mata pelajaran kimia Kelas X IPS SMA Negeri 2 Sukoharjo yang telah mengijinkan peneliti menggunakan kelasnya untuk penelitian.

\section{DAFTAR RUJUKAN}

[1] Depdiknas. (2003). Undangundang RI No 20 Tahun 2003 Tentang Sistem Pendidikan Nasional. Jakarta: Depdiknas.

[2] Slavin, R.E. (2008). Cooperative Learning Teori, Riset dan Praktik. Terjemahan Nurulita Yusron. Bandung: Nusa Media. 
[3] Purba, M. (2007). Kimia untuk SMA Kelas $X$. Jakarta: Erlangga.

[4] Nugroho, E. A. (2011). Perbedaan Hasil Belajar Siswa antara Model pembelajaran NHT (Numbered Head Together) dengan STAD (Student Team Achievment Division) pada Konsep Laju Reaksi. Hasil Penelitian Skripsi Universitas Islam Negeri Syarif Hidayatullah. HIm 61. Universitas Islam Negeri Syarif Hidayatullah, Malang.

[5] Chayati, N., Ashadi, Utomo, S.U. (2015). Studi Komparasi Model Pembelajaran Student Teams Achievement Division (STAD) dan Numbered Head Together (NHT) Menggunakan Modul Pada Materi Termokimia Kelas XI Semester Gasal SMA Negeri 1 Sukoharjo Tahun Pelajaran 2013/2015. Jurnal Pendidikan Kimia, 4, (4), 1-7.
[6] Arofati, Yuliesta. (2011). Penerapan Pembelajaran Kooperatif STAD (Student Team Achievement Division) Berbantuan Macromedia Flash dilengkapi Handout untuk Meningkatkan Kualitas Proses dan Hasil Belajar Asam, Basa, dan Garam Siswa Kelas VII B SMP Muhammadiyah 7 Surakarta Tahun Pelajaran 2010/2011. Hasil Penelitian Skripsi Universitas Sebelas Maret. HIm v. Universitas Sebelas Maret, Surakarta.

[7] Sudjana, N. (2005). Penilaian Hasil Proses Belajar Mengajar. Bandung: Remaja Rosdakarya. 